\title{
Can we save our resources with half-body-18F-FDG-PET-CT rather than whole-body, in the management of head \& neck cancers?
}

\author{
LI Sonoda*, A Lakhani, S Ghosh-Ray \\ From International Cancer Imaging Society (ICIS) 14th Annual Teaching Course \\ Heidelberg, Germany. 9-11 October 2014
}

\section{Introduction}

18F-FDG PET-CT plays a significant role in the management of head and neck ( $\mathrm{H} \& \mathrm{~N})$ malignancies. There have been recent suggestions that half-body (above diaphragm) PET-CT may be sufficient for the management of $\mathrm{H} \& \mathrm{~N}$ cancer patients. This study aims to determine if half-body PET-CT is a safe practice option, or should we stick to whole-body PET-CT.

\section{Methods}

A 6-year-period retrospective analysis of 729 consecutive PET-CT scans of H\&N cancer patients was performed in order to record the incidence of below-diaphragm metastases and below-diaphragm synchronous primary malignancies. The four main indications of PET-CT in $\mathrm{H} \& \mathrm{~N}$ cancers are; pre-treatment staging of high-risk of disseminated disease, metastatic cervical lymphadenopathy with unknown primary, assessment of therapeutic response and detection of recurrence/relapse.

\section{Results}

A total of 664 squamous cell carcinoma (SCC) and 65 nasopharyngeal carcinoma (NPC) cases were studied. 35/729 (4.8\%) of cases showed below-diaphragm metastases (liver, renal, adrenal, retroperitoneal and lumbar vertebral metastases), 24/664 (3.3\%) by SCC and 11/65 (16.9\%) by NPC.

$52 / 729$ (7.1\%) cases showed synchronous primary malignancies, of which 32 (4.4\%) were below-diaphragm (colonic, pancreatic, bladder cancers and retroperitoneal lymphoma).

In total, 84/729 (11.5\%) H\&N cases had either belowdiaphragm metastases or below-diaphragm synchronous primary malignancies.

\footnotetext{
* Correspondence: luke@sonoda.co.uk

Paul Strickland Scanner Centre, Mount Vernon Hospital, London, UK
}

\section{Conclusion}

A significant proportion of $H \& N$ patients, over $10 \%$, have either below-diaphragm metastases or below-diaphragm synchronous primary malignancies. Half-body (above diaphragm) PET-CT would have missed these lesions, leading to mis-staging of disease and mis-management of patients. It is important to keep whole-body PET-CT in practice in the management of $\mathrm{H} \& \mathrm{~N}$ cancers. This is more so in the management of NPC compared to SCC.

Published: 9 October 2014

doi:10.1186/1470-7330-14-S1-P2

Cite this article as: Sonoda et al.: Can we save our resources with half-body-18F-FDG-PET-CT rather than whole-body, in the management of head \& neck cancers? Cancer Imaging 2014 14(Suppl 1):P2.

\footnotetext{
Submit your next manuscript to BioMed Central and take full advantage of:

- Convenient online submission

- Thorough peer review

- No space constraints or color figure charges

- Immediate publication on acceptance

- Inclusion in PubMed, CAS, Scopus and Google Scholar

- Research which is freely available for redistribution

Submit your manuscript at www.biomedcentral.com/submit
}

() Biomed Central

(c) 2014 Sonoda et al; licensee BioMed Central Ltd. This is an Open Access article distributed under the terms of the Creative Commons Attribution License (http://creativecommons.org/licenses/by/4.0), which permits unrestricted use, distribution, and reproduction in any medium, provided the original work is properly cited. The Creative Commons Public Domain Dedication waiver (http://creativecommons.org/publicdomain/zero/1.0/) applies to the data made available in this article, unless otherwise stated. 